\title{
MATERIALISING HAMLET IN THE CINEMAS OF RUSSIA, CENTRAL AND EASTERN EUROPE
}

\begin{abstract}
In this discussion, I argue that Gamlet (dir. Grigori Kozintsev, 1964) establishes a template for interpretation that has shaped the thinking of subsequent filmmakers. The Russian black comedy Hamlet adaptation, Playing the Victim (dir. Kirill Serebrennikov, 2006), is a salient example. It is against the backdrop of huge material challenges, exacerbated by the budgetary crises that went hand-in-hand with the collapse of Central and Eastern European communist systems, that I go on to discuss Hamlet, Ciganski Princ (dir. Aleksandar Rajković, 2007) and Cigán/Gypsy (dir. Martin Šulík, 2011), respectively Serbian and Slovakian adaptations. Consorting with the gloomy outlook of Playing the Victim, they offer irredeemably bleak visions that admit of no different prospects for their subjects.
\end{abstract}

Key words: Shakespeare, cinema, Russia, Central/Eastern Europe

The critical consensus is that Gamlet (dir. Grigori Kozintsev, 1964) represents an apogee of achievement and authority. ${ }^{1}$ Accordingly, this Hamlet adaptation is seen as a remarkable summation of an extended history of Russian engagements with Shakespeare in literature, film and on stage. ${ }^{2}$ Critics have approached the film broadly - as a product of Kozintsev's background in avant-garde theatre, as a harmonious interaction between the Boris Pasternak translation and the Dmitri Shostakovich score, as a concerted attempt to resurrect a play vilified by Stalin, as an anti-psychological treatise and, most often, as a retrospective "Aesopian" political fable about Russia in the Soviet era. ${ }^{3}$ In this paper, I want to think about Gamlet not so much as an endpoint than as a beginning. In short, I want to think about the Hamlets that came after,

\footnotetext{
“School of Arts, English and Languages, Queen's University, Belfast, BT7 1NN, Northern Ireland, UK; e-mail: Mark.Burnett@qub.ac.uk

${ }^{1}$ An earlier version of this paper was published in Burnett (2019: 219-251). I am grateful to Cambridge University Press for permission to re-use some of that material.

${ }^{2}$ See Osborne 1995: 325-347; Rowe 1976: passim; Sokolyansky 2014: 312-316.

${ }^{3}$ See Burke 1997: 172; Collick 1989: 129, 135, 137, 139, 141; Leaming 1980: 1, 14, 17, 25, 34, 95; Makaryk 2006: 120; Sokolyansky 2007: 205; Thomas 2014: 58-96.
} 
the new generation of Russian, Central and East European cinematic Shakespeares. I discuss three Hamlet adaptations, all made in the last thirteen years. The first is the award-winning Russian black comedy Hamlet adaptation, Playing the Victim (dir. Kirill Serebrennikov, 2006). The second and third are the Serbian Hamlet, Ciganski Princ (dir. Aleksandar Rajković, 2007) and the Slovakian Cigán/Gypsy (dir. Martin Šlík, 2011). All three films jettison Shakespearean language in order to chart the residues and remainders of a post-communist moment and identify material need as the agent that shapes the lives of the most marginalised. In this way, they are the inheritors of Kozintsev's sense of Hamlet, continuing in the vein of interpreting the play in a materialist fashion but simultaneously demythologising and problematising its portrayal of the prince.

Playing the Victim takes to an extreme the situating of the play in reduced and straitened settings. Because the film prefers a stylised narrative mode, the city of Ekaterinburg, in which the action takes place, becomes an "everywhere", and Valya/ Hamlet (Yuri Chursin), the protagonist, a corresponding "everyman". Crucially, Valya/ Hamlet, a thirty-year-old former student never without his trusty baseball cap and casual wear that has seen better days (his South Park T-shirt aligns him with surreal humour and antagonistic energies), works for the police, standing in for the "victim" in filmed crime scene re-enactments which are then used as legal "evidence" (he signifies, then, as play, proxy and absent material body). Continually admonished and treated only in terms of his physical instrumentality, he is more broadly represented as infantilised, as his dingy bedroom stuffed with plastic toy animals confirms; in this alone, Playing the Victim demonstrates its distance from Kozintsev and partnership with a subsequent parodic Hamlet trajectory. In a nondescript apartment, which Valya/Hamlet shares with his family (the Shakespearean royal family is pointedly debunked), a petty bourgeois Hamlet plot unravels: Old Valya/the Ghost is poisoned (during a "usual dinner") by Valya/Hamlet's mother, Galya/Gertrude (Marina Golub), and uncle, Petya/Claudius, bringing to a head the protagonist's acerbically realised angst. Old Valya/the Ghost and Petya/Claudius are played by the same actor (Fyodor Dobronravov), suggesting the repetition of, and currents running between, domestic abuse narratives. When Valya/ Hamlet is woken at night by Old Valya/the Ghost, a sea-captain in a peaked cap and epaulets, and made aware of the suspicious circumstances surrounding the death, the spectral father simultaneously reprimands him for wasting electricity. Underpinning the conceit of Playing the Victim is an envisioning of Valya/Hamlet as a source of paternal disappointment, a son incapable of living up to the image and institutional respectability of his seafaring father.

Playing the Victim affirms its investment in summoning and deflating Hamlet through domestic detail. Glimpses of empty bottles, bare floorboards and unfinished 
walls evoke the cheerlessness of the shared space, while unforgiving lighting and an off-kilter shooting style (the camera captures family squabbles from inside fridges and wardrobes) accentuate the sense of a run-down high-rise habitat. The layout of the apartment lends itself to performative hyperbole, as when Valya/Hamlet (in a scene that replays Polonius' invitation to "walk out of the air" [2.2.203]) unwillingly accepts Petya/Claudius' request that he step out onto the balcony, only to end up in a tussle with his overbearing uncle. ${ }^{4}$ Similarly, around the tiny apartment dinner table, Valya/Hamlet (using chopsticks) and Petya/Claudius (wielding a spoon) argue over how best to eat, taking up diagrammatically opposed views about, on the one hand, the dissolution of "East ... West ... borders" and, on the other, "our Russia": the generational conflict suggests competing notions of cultural-national integrity. In this Hamlet adaptation, warring implements of sword and rapier are bathetically reimagined as common household utensils.

Hamlet is adumbrated in Playing the Victim in citation, echo and inference. For example, when Karas (Marat Basharov), the first of the accused, is asked about the mutilated body of his girlfriend ("Where did you put the pieces?"), lines from the play filter to the surface ("you must tell us where the body is" [4.2.23-4]), the effect of which is to underscore a grotesque comic consanguinity. Hamlet stores Polonius in the "lobby" in contrast to Karas who disposes of his victim in a public eco-toilet. Similarly, the scene in which a naked Valya/Hamlet asks Olya/Ophelia (Yelena Morozova) to "scarf" (asphyxiate) him smacks of the scene in which Hamlet appears before Ophelia with "his doublet all unbraced" (2.1.75): the parallel pushes at the sexual charge of the Shakespearean encounter to spotlight a relationship comically premised on erotic extremity. Poison in Playing the Victim, as in Hamlet, is the means of getting rid of Old Valya/the Ghost, although the film is more extensively concerned with toxicity, the theme erupting in Valya/Hamlet's warning not to buy "poisoned" Armenian and Turkish lavash flatbread (as opposed to the Russian Moscovsky or Moscow "long loaf'); here, he sends up ethnocentric attitudes even as he arraigns the contaminating and contaminated forces of his world. Foodstuffs in the film, indeed, form a bridge between its various re-enactments. In a later scene in a Japanese restaurant, a drunken and elderly Russian hostess (Liya Akhedzhakova), wearing a kimono and flowers, sings to a karaoke machine a sentimental folk song in which a "beautiful Japanese girl", impregnated and abandoned by an "English ... sailor", answers her son's questions about his paternity. In that the hostess' performance indexes Ophelia's song about "Saint Valentine's Day" (4.5.48), the frame of reference is Shakespearean, only Playing the Victim plays a variation on the theme, identifying parody in the disappointments of an older woman and seeing in her a sad reminder of her much younger dramatic

\footnotetext{
${ }^{4}$ Hamlet 2016. All further references appear in the text.
} 
equivalent. Aleksei Semenenko writes that "allusions to Hamlet" in Playing the Victim "have no direct function and serve as an empty signifier, emphasising the absurdity of the action and life as a whole" (Semenenko 2011: 253). But his observation is only partially true. Severed yet suggestive, meaningful yet misplaced, bits and pieces of Hamlet in Playing the Victim emblematise what is left - after Kozintsev, after the fascination with Hamlet as an inviolable text had faltered, after the break-up of the Soviet Union. What remains are referents whose power inheres precisely in their fragmentary appearances.

If Hamlet is pervasive in Playing the Victim, so, too, is "To be, or not to be". Its either/or sentiments are everywhere - in the "scarfing" episode, in the general cultivation of suicide chic and in the major exposition of the soliloquy, the scene in which Valya/Hamlet imagines throwing himself off a grimy stairwell, murmuring to himself not Hamlet's words but "I live ... I don't live", a satirically realised firstperson balancing-act between different destinies. Writing on the "mental health ... crisis" of the Putin era and the rising incidence of "psychoses ... schizophrenia ... and mental disorders as a whole", David E. Powell notes that "treatment facilities and ... government support" have proved "grossly inadequate", and it is within these contexts that Valya/Hamlet's condition takes on a peculiar urgency (Powell 2005: 113). Psychic imbalance in the film is a constant, with blue-filtered lighting in the bedroom scenes suggesting an altered state of mind. At one point, in an echo of Hamlet's putting on of an "antic disposition" (1.5.170), Valya/Hamlet dons a rabbit mask, becoming one with the toys that litter the floor. On other occasions, he imitates Christ ("They pierced his ribs") and mimes, in the same outburst, interrogation procedures ("Second Infantry, please don't!"), an imam's prayers, sounds of explosions, presidential announcements and the public response to 9/11: "Oh no, why Mr President?". Taking their cue from Hamlet's "confusion" (3.1.2) and "wildness" (3.1.39), these episodes help to construct Valya/Hamlet in terms of an excess that shows itself in media saturation and disorientation. At the same time, references to martyrs past and present speak to the ways in which Valya/Hamlet sees himself in terms of victimhood, as fighting his own war on domestic terror.

Black-and-white animation sequences inter-spliced with the apartment scenes emphasise the idea of a pent-up protagonist: combining cinematic surrealism, painterly symbolism and Shakespearean allusion, they feature drilled skulls as motifs of disturbance. In the final animation sequence, a shot of a skull, subsequently superimposed on Valya/Hamlet's face, bobbing in the ocean hints at his demise, while, in an earlier bedroom scene, the camera's lingering on a television manga cartoon inset of a pig being cut up and fried in a pan suggests how he is divided from himself. Via imagery of chopsticks as weapons, these sequences are particularly suggestive of 
Valya/Hamlet's fantasies of revenge. A lover of retro Japanese pop music, and a fan of U.S. popular culture, Valya/Hamlet is represented (at a time when Russia is "looking westward for ... welcome, yet ... [keeping] ... its options to the East wide open") as continually in search of points of identification (Black 2004: 348). Invariably ignited by domestic crises, animation in Playing the Victim conveys an inability to express, and an underlying rage, of nightmarish proportions (Valya and Hamlet alike suffer from "bad dreams" [F, 2.2.18]). "To be, or not to be" is everywhere not least in part because its themes of ressentiment and extinction are also rehearsed in the animations that are so integral a part of Valya/Hamlet's afflicted imagination.

Picking up on the Hamletian mindset, Valya is cynical, berating to camera how "Russian cinema is fucked". "Fyodor Bondarchuk is the only one who rocks", he states, adding, "his father won an Oscar: he'll win one as well". Instancing the success of the Bondarchuk-directed war film, $9^{\text {th }}$ Company (2005), but taking an adversarial attitude towards the resurgence of nationalism in the Russian "blockbuster" genre, Valya/Hamlet emphasises the cronyism and nepotism informing the industry and subscribes to a fatalism that illuminates the ways in which, in Playing the Victim, the metatheatrical is envisaged in metacinematic terms. "The purpose of art", he reflects, "is self-sacrifice", a pronouncement that references Hamlet's observation that "the purpose of playing ... is to hold ... the Mirror up to Nature" (3.2.20-22) and that establishes Valya/Hamlet as a stymied creative practitioner. Indeed, the melodramatic relish with which he takes on the role of victim points up how Valya/Hamlet conceives of himself as a type of free-wheeling, postmodern performer. The "crimes" investigated through re-enactment in Playing the Victim are familial-domestic revenge tragedies explained as accidents (they are "casual slaughters ... for no cause" [5.2.366, 367]). So, Karas stabs his girlfriend in the park, Sysoev (Andrei Fomin) pushes his wife out of a window, Zakirov (Igor Gasparian) drowns his lover in a swimming pool, and Verkhushkin (Maksim Konovalov) shoots his college friend in a restaurant, and it is as the "accidental" victim that Valya/Hamlet comes into his own, his police work indicating a sense of self defined through the rehearsal of other fractured identities. In a conflictual relation with his family, Valya/Hamlet connects only with the victims whose deaths he enacts for the legal record and is animated only through ironically realised impersonations.

Prioritising re-enactments, Playing the Victim, in fact, structures itself around the conceit of the "dumb show", the premise being that, by making manifest the victims' experiences, the material "truths" of the circumstances of their deaths will emerge (each "play" ideally works to "catch ... conscience" [2.2.539-540]). In Hamlet, of course, The Mousetrap is also the reconstruction of a crime, with Playing the Victim

\footnotetext{
${ }^{5}$ See Norris 2012: 111-112, 143-154.
} 
taking that central idea and elaborating it several times over to suit the film's narrative logic. However, as in the play, in which Horatio is distinctly non-committal about the success of The Mousetrap as a force of exposure ("I did very well note him" [3.2.282]), what is enacted in Playing the Victim introduces more doubt than it does clarification. Key claims in the testimony are never precisely established, meaning that the findings of the multiple investigations remain inconclusive. Commenting on Russia in the late twentieth and early twenty-first centuries, Steven Rosefielde and Stefan Hedlund note how "gains" have been "offset ... by eviscerated democracy ... ordinary people ... remain disenfranchised ... and have partly or wholly lost many former constitutional ... protections", and, in this light, the filmic representation of the accused - Zakirov, whose diminutive stature and Middle Eastern accent mark him out as "the other", or Verkhushkin, whose anxieties about his manhood and the economy impel him to violence - takes on a sharp suggestiveness (Rosefielde and Hedlund 2009: 206). All are locked in destructive and self-destructive behaviours. Failing and unfulfilled in a bleakly comic vein, the accused analogise the diminished and uncertain subjects of the eclipsed Russian proletopia.

Playing the Victim invites an empathetic response to the accused in part because it represents the investigating force as incompetent and corrupt. Inadequacies are comically highlighted in Lyuda/Horatio (Anna Mikhalkova), the distracted officer who records the re-enactments on her camera: she allows her focus to wander, or concentrates on the wrong object, an instance of Shakespearean delay. But they are more critically identified in the ways in which the police operate coercively. Unlike the typical Russian television crime series in which, as Birgit Beumers states, the morally upright "policeman ... is the winner", Stasik (Vitali Khayev), the police captain in Playing the Victim, is disinterested in the truth, bullies other officers and subjects the accused to violence (Beumers 2009: 242). He functions as a satirical incarnation of the ways in which recent "police re-empowerment" in Russia, together with "increased economic, political, social and civic repression directed against selected individuals and groups", have exacerbated "corruption ... brutality [and] judicial malpractice" (Rosefielde and Hedlund 2009: 206, 208). Stasik implodes in the Japanese restaurant, purposefully eating the "poison" fish, fuga, to tempt disaster ("It's a global fuck-up!"), indulging in a homophobic rant ("fucking faggots!") and excoriating the Russian football team ("every championship goes to shit!"). A flawed Fortinbras, strongarmed but ineffectual, he resonates as a fundamentally damaged authority, every bit as troubled as those whose fates he oversees. In this sense, Playing the Victim purposefully demythologises any expectation of hierarchical integrity.

It is in a netherworld of compromised categories and overlapping classifications that Playing the Victim makes its most corrosive statement. At the close, Valya/Hamlet 
poisons his family at his engagement party, and Olya/Ophelia, Galya/Gertrude and Petya/Claudius die at his hands. Crucially, in a reversal of the film's dynamic, Valya/ Hamlet here leaves behind him his substitute designation and joins the ranks of the accused; he is the "thing ... itself" (1.4.67) as opposed to a body double. Tracing the Hamlet plot from victim to revenger, Playing the Victim puts Valya/Hamlet at the centre of a "real-life" crime and its re-enactment, suggesting how he graduates from frustrated creative to scripting auteur. As such, he plays the starring role and, briefly, is given a new lease of energy, as indicated in the recharged battery icon showing on the camcorder. And, suiting the film's hyperbolic ethos, the Shakespearean plotline is affirmed if not exceeded: Valya/Hamlet executes a revenge never required of him in Old Valya/the Ghost's revelations. Even though, as Birgit Beumers and Mark Lipovetsky argue, Valya/Hamlet's revenge signals "an attempt[ed] departure beyond the limits of ambiguous norms", he remains in a muddled and limbo-like state (Beumers and Lipovetsky 2009: 298). First, in the same way that Hamlet ends with a synopsis of "accidental judgements" (5.2.366), Playing the Victim closes with a statement that foregrounds the contingent and unpredictable. "I didn't know for sure whether they'd be poisoned or not", Valya/Hamlet explains, situating his crime in a Russian roulette universe in which nothing is definite. Second, rather than confessing to motive, Valya/ Hamlet is represented as still storytelling, worried about how material deaths will be realised on film: "I was ... observing, trying to remember [how] ... to re-enact it ... [I knew that] you'd need to know exactly how all this happened", he tells his police colleagues now captors. Complicating things still further, Playing the Victim suggests that Valya/Hamlet's actions precipitate both his own death (imprisonment by the state) and a symbolic death thanks to his father's ghostly return (Old Valya/the Ghost is represented first as judge and then as executioner). In a black-and-white epilogue to Playing the Victim, Valya/Hamlet, roused from sleep, finds himself in a boat with his seafaring father, only to be cast into the sea and sink beneath the waves. The episode brings to a head the film's discovery of Valya/Hamlet as haunted by memories of traumatic childhood swimming lessons (in this sense, the maritime memorabilia on the apartment walls betoken a history of paternal-filial tensions) and as crushed by familial and institutional praxes. As Valya/Hamlet disappears, the camera, specked with droplets, is the only witness. Horatio's perspective may be intimated, but, with the water engulfing a darkening scene, it is in fact no more than a disembodied point of view that remains. In this post-Soviet Hamlet, the protagonist, as at the end of Kozintsev's Gamlet, is aligned with the natural element of the sea, but with no attendant hint of social or political recovery.

Independently conceived, Hamlet, Ciganski Princ (dir. Aleksandar Rajković, 2007) and Gypsy (dir. Martin Šulík, 2011) share the uncompromising outlook of 
Serebrennikov's Playing the Victim. Both match their characters to inhospitable terrains and highlight via minority narratives the travails of Romani experience. Concerned with a displacement that has pushed existence onto the margins of the cityscape, Hamlet, Ciganski Princ unfolds on a landfill site (Deponija) on the outskirts of Belgrade. The film makes a symbolic virtue of piles of débris: mountains of waste approximate Elsinore's battlements, stacked tyres suggest a graveyard. This is a soulless and monstrously impoverished world where acts of surveillance serve to accentuate living conditions grimly lacking in privacy. Such a melancholic situation is also registered in the film's tense, irreverent atmosphere. The oscillating light thrown by guttering fires, combined with the flicker of shadows, impart an eerie glow to the proceedings, while encroaching darkness hints at undiscovered black deeds. Daytime shots of swarms of gulls flocking about the dump operate as apt expressions of the Shakespearean Hamlet's cynical references to the "kites" of the "region ... fatted" with "offal" (2.2.514-15) even as they also communicate the merciless codes of a universe in which one either scavenges or is scavenged in turn. The setting, in fact, references the situation of some 100,000 Romani families who live in Belgrade recycling plastic and metal and brings to mind Hamletian metaphors and interests, as reflected in the details of the "unweeded garden" possessed by what is "rank and gross" (1.2.1356) and "something [that] is rotten in the state" $(1.4 .90) .{ }^{6}$ It is, then, in unremittingly hostile landscapes that Hamlet, Ciganski Princ most powerfully articulates a signature strain of hopelessness. Inside such an environment, when Hamlet (Igor Đorđević) is reduced to defecating in the grass or breaking the ice on his pail of washing water, his question, "Is there any place worse than this?", a rendering of the Shakespearean idea of a "stale, flat, and unprofitable ...world" (1.2.133-34), takes on an awful appositeness. In addition, frozen ground and a weary colour-scape suggest a dystopian revision to a "gypsy" film aesthetic centred on, as Caterina Pasqualino puts it, "an unadulterated community living in delightful harmony with nature" (Pasqualino 2008: 343). Fired by the currency of Shakespeare's language and imagery, Hamlet, Ciganski Princ dismisses the paradigm as unequal to the task of representing late twentieth- and early twenty-first-century Romani realities.

Gypsy similarly concentrates on the marginal - up to 320,000 Romanies inhabit Slovakia - although the locus of attention in this adaptation is a shantytown in Richnava, Eastern Slovakia (Filčák 2012: 45). The opening romantic images of Adam/Hamlet (Jan Mizigar) bounding through a lush forest with his dog, running down through the trees to a gently undulating river, quickly shift: once the gaze transmogrifies and alights on the shantytown, perched precariously on a scarred hillside, the urgent exigencies of his life become the focus. Attempts to alleviate monotony -

\footnotetext{
${ }^{6}$ For the Roma and Belgrade, see 'Severed Lives' (2010: 42-43).
} 
the camera picks out a makeshift game of table tennis - can do little to detract from more pressing material requirements, as instanced in shots of roofs being repaired, a sheep being skinned, wood being hewn and tatty furniture being laboriously moved up a precipitous pathway. Clustered tightly together, the shantytown's flimsy dwellings are a patchwork of shapes and colours, but there is little sense of security or comfort. As in Hamlet, Ciganski Princ, repeated establishing shots of an unwelcome scene have an oppressive effect. For example, the mise-en-scène picks out open sewers traversing cratered, half-finished roads and chimneys belching smoke into otherwise clear skies - even as vestiges of the pastoral intrude, the impression is of desperate environmental conditions. The shantytown is additionally bisected by a train-track, but the train speeds through without stopping: the implication, in Frantz Fanon's phrase, is that Adam/ Hamlet's world is a "zone of non-being" which has been edged to the side-lines of the Central European imaginary (Fanon 1986: 2). In Shakespearean terms, the "goodly frame the earth", then, appears as an isolated "promontory" (2.2.264-65), unforgiving and inimical. Hamlet, Ciganski Princ - in which steaming methane vapours point up a sense of stagnation and aftermath and in which metaphysical questions are posed amidst dirt and detritus - again invites comparison. The equivalent view in Gypsy is realised in rhythms and visuals. After a spring start, the film moves to winter, and it is this season that dominates the second half. The camera now identifies snow falling, a woman struggling with a bundle of sticks and youths pushing a car that has stalled in the cold, while the sonic scene is pierced by dogs barking with increasing frenzy "The air bites shrewdly" (1.4.1). Dividing up the action in this way, the film deploys natural processes to underline the escalating dominion of want.

The kinds of deprivation explored in Hamlet, Ciganski Princ and Gypsy are congruent with the effects of the collapse of state socialism and an "unfavourable starting-point" for the Roma "at the outset of the transition from planned to market economies" (Ringold, Orenstein and Wilkens 2005: xiv). Hamlet, Ciganski Princ indexes the "problem" of the Roma peoples via rubbish - working with rubbish, and becoming indistinguishable from it, illuminate the material ramifications of state policies towards minorities and the divisive consequences of the Balkan crisis. As the fool figure, a cinematic chorus, announces to camera at the start in an exclamation that equates demographics and dross: "Goddam gypsies! You're scumbags!". Beyond this, and certainly in the former Czechoslovakia, laws restricting itineracy, the liquidation of settlements, efforts to assimilate Romanies as part of the socialist initiative, interment and even genocide are the constituent components of traumatic memory. After 1989, for Romanies in Slovakia, as Will Guy argues, the "break-up of the federal Republic led to an immediate deterioration of their position" (Guy 2001: 229). Most recently, in the winter of 2003/2004, there was a wave of protests in Roma communities, resulting in 
the mobilization of the army, against cuts in social benefit introduced by the neoliberal government (Marušak and Singer 2009: 186). Across Central and Eastern Europe, Romanies have fared poorly as newly constituted nation-states pursue intersecting agendas of identity formation and capitalist enterprise.

The situation is expressed with heightened eloquence in Gypsy's representation of male-on-male and father-son relations. Within contexts of enforcing peripheries, the film's figuration of Emil/the Ghost and Žigo/Claudius (Miroslav Gulyas) as embittered and disappointed serves a key purpose. Wearing a shabby outdoor coat, Emil/the Ghost visits Adam/Hamlet to lament how monetary needs, and family disputes, got in the way of knowing his son properly. Emil/the Ghost itemises a series of crises - prison, the death of a daughter, an alcoholic father - that robbed him of masculine agency and visibility. As Gypsy makes clear, Emil/the Ghost is also deceived by the "white" community he embraced as a Christian convert. His admission - "They tricked us: Heaven doesn't exist, God only has a small office up there, and there's a long queue in front of it" - works less as a précis of purgatory than as an example of how in life as in death he is denied a better dispensation. In this outlining of his experience, established religion plays a prominent part. The church, it is implied, keeps Romanies submissive, and the critique extends even to the priest (Attila Mokos) who, standing in for Horatio, is represented as attentive to Adam/Hamlet's "story" (5.2.333) and keen to transform his lot via the boxing club but ultimately powerless. Repeated shots of Catholic icons are indicative here, suggesting, as they do, that the church's overseeing functions exist only at the level of the image.

Both the priest and Žigo/Claudius, whose tattered T-shirt with a crown motif proclaims him king or, in the film's terms, community fixer and "loan-shark", attempt to exercise paternal responsibilities in their relations with Adam/Hamlet. In confessional vein, Žigo/Claudius seeks to find accommodation with Adam/Hamlet through advice and discourses of gypsydom and commonality - "the whites ... beat the crap out of them ... I have nothing in common with those bastards ... be a gypsy", he urges. The instructive tenor of his words reveals how keenly Žigo/Claudius agitates to win Adam/ Hamlet over and create a bond, and it is by mobilising binaries between gypsies and "whites" (rather than between Adam/Hamlet and his biological father) that he argues his case. His elevation of ethnicity is accentuated when, in the hospital, and in the same way that Claudius declares "the most immediate to our throne" (1.2.109), he announces the arrival of his child with group rather than national pride: "another gypsy has been born", he exclaims. And it is arguably against histories of persecution that we need to read Gypsy's elaboration of the wake, the wedding between Žigo/Claudius and Jolana/ Gertrude, Emil/the Ghost (presented in terms of cinematic realism) and the song (a 
type of "dumb show") about escaping "poverty". 7 Countering the romantic or magic realist gypsy screen visions of auteurs such as Dušan Hanák and Emir Kusturica, these elements make visible Roma cultures in ways that are integral and assertive while being resistant and rehabilitative at the same time.

A will to enshrine if not protect Roma traditions is shared across both films. Hamlet, Ciganski Princ, for example, is notably responsive to the occluded cultures of an older Yugoslavia, as in its representation of the chief bear-tamer (the film's substitute for the travelling player), whose tambourine, tinkling bells and incantatory snatches of folk song bring to mind a disappearing mode of representation. At a deeper level, the fact that the bear-tamers are travelling evokes the kinds of displacement often forced upon the Roma, making them emblematic of the mobile existence dictated to by the pressures of inhabiting societies in flux. Gane/Guildenstern (Zdravko Ranković) notes of the bear-tamers' incongruous winter visit to the dump, "Everything changes, no one is interested in bears, and television has ruined everything", his comment registering the extent to which a global media industry has swamped localism and homogenised cultural diversity. The point is stridently made in Gypsy in which the camera repeatedly pauses for several beats on satellite dishes adorning the fronts of the shantytown dwellings. A disconnect between technology and a primitive backdrop is underscored, while the multiplication of dishes suggests an invading force, a militaristic onslaught that threatens to ruin Roma distinctiveness.

The surfaces of technology mask underlying privations and lack, a state of being which in both films is understood primarily in economic terms. In Hamlet, Ciganski Princ, the aberrancies of the system have made Jova/Claudius (Petar Božović) viciously acquisitive. As he discloses in confession, he murdered Đura/Old Hamlet (Dragoljub Topalović) "because of the money", the equation between cash and crime being reflected in shots of wads of notes concealed in a makeshift outside toilet. That this is dirty money the toilet analogy makes explicit, but there is also the suggestion of the desperate lengths to which the inhabitants of the dump are prepared to go to ensure survival. The absence of money provokes correspondingly anxious actions which are best illustrated in the scene in which Jova/Claudius, sitting behind a glass door and counting his ill-gotten gains, argues with one of his young henchmen: "That's all?", he demands, his question pointing up the fact that he requires more but that there is no more to give. More broadly, the dump is discovered as a place where rubbish figures as a commodity around which the film's substitutes for political powers conduct a deadly trade. The backstory to Hamlet, Ciganski Princ centres on the conflict between rival Orthodox Roma and local Muslim gangs who wish to control the rubbish empire: the dump, then, is both domain and kingdom. (For its part, Gypsy's equivalent contest is

\footnotetext{
${ }^{7}$ See Kaldova 1991: 105; Matras 2015: 93, 98, 100, 101.
} 
between the Roma, representing Denmark, and the "whiteys", representing Norway). Notably, Jova/Claudius is represented as adulterating commodities when dealing with Murat/Old Norway, selling paper that is dampened to increase its weight and worth: in this environment, one witnesses pervasive interlacing of the fraudulent and the economic.

In Jova/Claudius' estimation, people, too, are commodities to be managed via his own brand of backhanders. "How much did he give you?", Hamlet demands of Gane/Guildenstern and Mija/Rosencrantz (Jovan Fetouski), his immediate suspicion being that Jova/Claudius pays people off and that the fawning pair are motivated by a common venality (the play's euphemistic reference to "thanks / As fits a king's remembrance" [2.2.26] is here baldly translated). But the needs of the economy in Hamlet, Ciganski Princ do not level in a unifying fashion. Zoran/Laertes refuses Jova/ Claudius' offer of money in the wake of Duško/Polonius' death, his angry exclamation testifying to his integrity and to something more important than mere financial gain. Even more removed is Hamlet. There is only one occasion on which he handles cash; Hamlet asks the bear-tamer, "Listen: do you know how to perform?", and afterwards discreetly passes him some notes, an act that is justified in that it supports the traditional moral efficacy of the "artist". If the protagonist is revealed as indifferent to the "business" being transacted around him, then he also apprehends rubbish less as a commodity than as a collection of aesthetically arresting objects, such as in the scene where, in a reworking of the play's sexual concern with "treasure open" (1.3.30) and "memory locked" (1.3.84), he picks up a key, remarking to Zorica/Ophelia (Mirjana Šišić), "They never think about using the old stuff". This and similar exchanges mark out Hamlet's difference - his equitable relationship with Zorica/Ophelia, his ecoinstincts, his alternative notions of value. Hamlet is characterised by self-denial: his is not the realm of expenditure. A not dissimilar imagining of Hamlet undergirds Gypsy, for, in this adaptation, Adam/Hamlet is represented as resisting the pressure to steal, attracting in the process a "faggot" designation: masculinity and crime are inseparable.

In both films, indeed, the Hamlet character stands out from the rest. Gypsy takes the idea to an extreme in its rendition of Adam/Hamlet, fifteen years old, lustrous-eyed and tousle-headed, struggling with his place in the community. Janet Adelman notes how Gertrude is imagined as a "contaminating material body ... the object of moral revulsion", but, in Gypsy, her oppressed - and pregnant - condition necessitates Adam/ Hamlet's assumption of the bread-winner role: it is to alleviate her circumstances that he tries to "make money" and gives up his education (Adelman 1992: 14, 15). Throughout, he is impelled to take on a responsibility beyond his years (a princely burden is placed on his shoulders). Pregnancy, as Gypsy and Hamlet, Ciganski Princ establish, makes women vulnerable, the latter film illustrating the point with Shakespearean 
specificity. When Jova/Claudius forces himself on Jelena/Gertrude (Suzana Petrović), for example, she fears another pregnancy as a result (the reference to the "enseamed bed" [3.4.90] is graphically realised). By contrast, in Gypsy, Shakespearean echoes cluster mainly around Adam/Hamlet who, in a series of insets, is represented looking directly to camera (interestingly in weather that is increasingly harsh and adversarial). The device meets the requirement of the soliloquy, silently communicative moments standing in for the verbal richness of "To be, or not to be".

Yet, as the film simultaneously establishes, Adam/Hamlet from the perspective of the wider world is far from individuated, and his characteristic sports-top "hoodie", stamped with an "86", suggests how Romanies are invariably seen in anonymous, statistical terms. Underlying each of Adam/Hamlet's encounters in Gypsy is the systemic and structurally engrained racism that works, in Aidan McGarry's words, as a "legally sanctioned form of discrimination", a synthesis of "anti-Roma prejudice" (McGarry 2017: 2). A loose reworking of the "closet scene", the episode in which Jolana/Gertrude is kept in hospital after the birth of her child is a salient instance. Visited by her family on the ward, and interrupted by the nurse (a type of Polonius), she is generally demeaned ("This place is driving me nuts ... They said they'd put the baby in an orphanage"), to the extent that the hospital appears more incarcerating than recuperative. Similarly, when Adam/Hamlet and his brother, Marian, are gaoled after being caught as part of a gang stealing diesel, the brutality to which they are subjected by the police confirms the anti-pathetic mentalities of social institutions. At a more general level, when Adam/Hamlet is ostracised from casual employment ("Don't come tomorrow: no work") or chased through the woods by the police, the film exposes praxes of dehumanization which portray him as quarry and blur animal and human taxonomies.

Whether imagined or "real", animals in both films are thematically purposeful. A traditional aspect of gypsy culture serves narrative priorities. For example, in Hamlet, Ciganski Princ, different attitudes towards animals bring differences between Jova/ Claudius and Hamlet to light. The white rabbit that the protagonist cradles hints at his solicitude while, in the same moment, suggesting an Alice-in-wonderland type of distraction and an alliance with his white-suited ghostly father. In contradistinction, the pig that Jova/Claudius fondly scratches pejoratively resembles, in its fleshy proportions, the form of its master, for not only does the creature tar the king with its significances, reinforcing the brute notion and explicit imagery of "making love / Over the nasty sty" (3.4.91-2), it also reveals the workings of a regime in which humanity itself is treated in animal-like ways. Thus, in the scene where the pig is disembowelled, the suggestion is that Hamlet, recently exiled to Vienna and his death, is a further sacrifice: he will be dispatched at the hands of those fawning followers who will "pluck out the heart of 
[his] mystery" (3.2.357-58). Crucially, the pig is killed because it is deemed valuable (it is roasted and eaten), whereas the white rabbit, glimpsed later dead in its cage, is appreciated simply for its own sake. However, in a violent extension to the animal analogy, the film reveals how it is Gane/Guildenstern and Mija/Rosencrantz who will suffer a fate that makes them the objects of sacrifice. Trussed up like pigs for slaughter, the roped pair is burned alive in a car which then ends up, with its conflagrated contents, as another piece of trash. Their deaths are at one with the animal economies of the dump that proves their undoing. Over the course of Gypsy, Adam/Hamlet's hopes and projections are consistently deflated. Associated with berries and fertility, Julka/Ophelia (Martina Kotlarova) is bartered for in such a way that she blights his romantic aspirations. Her status as sexual commodity is settled when she is sold off to a "Czech guy", the transformation being highlighted in the sequence where, inexpertly made-up, and stumbling on high heels, she informs Adam/Hamlet of her departure. The widescreen shot of her leaving the shantytown in a glimmering Mercedes replays the nunnery scene in a different key, echoing Shakespearean accusations ("I have heard of your paintings ... You jig and amble" [3.1.141, 143]) inside an unpalatable "deal ... the family needs the money". The Shakespearean plotline of madness and drowning cedes place to a concentration on Julka/Ophelia's utility as an object of exchange.

What might be entailed in leaving a familiar environment is a question asked by Hamlet, Ciganski Princ and Gypsy alike. Each film ends by steering a course between the pressures of moving on or staying put. Typical is Hamlet, Ciganski Princ in which, captured in a widescreen shot that encompasses a comprehensive point of view, the fool abandons the dump in the company of the travelling bear-tamers, the implication being that they are embarking on a journey. The fool and the bear-tamers find, in their association, a common purpose. The departure comes hard upon the knife fight between Hamlet and Zoran/Laertes which, echoing a playful fight between children at the start, shows the rival combatants participating, as in the play-within-the-play, in a dreadful entertainment. And, while the order that Hamlet represents passes (his body is laid out on a pyre, and gulls congregate to feed on the remains), the rubbish empire continues. Thanks to an earlier deal Hamlet has made with Meša/Fortinbras ("Meša will get what's his, and he'll start over again: it's only fair", the protagonist states), the rival Muslim Roma gang now takes charge. Meša/Fortinbras enters the frame to claim his dues; he is rubbish-as-commodity's elected heir. Hamlet, Ciganski Princ, then, ends poised between scenarios: one concerned with movement, the other concerned with the perpetuation of a degraded and degrading economy. Crucially, neither scenario represents an alternative; rather, marshalling all too recognizable tropes of travel and penury, the film highlights the impossibility of meaningful change, the lack of solutions, and ongoing confrontations with material imperatives. A comparable state of affairs is 
represented in Gypsy, although the stress in this adaptation is less with the situation of the community than with the plight of the individual. The knife fight approximation of the Shakespearean duel is again enlisted, with Adam/Hamlet, having pieced together the facts and realised that Emil/the Ghost did not die in a "car accident", stabbing Žigo/Claudius to death during a break in their journey to the hospital, only to find himself stranded at an out-of-the-way bus-stop. Enacting gypsy law, however, as the ending clarifies, has no ameliorative effect, for Adam/Hamlet is still locked in the either/or dichotomy that has defined him, divided between the shantytown and "white" society beyond. ${ }^{8}$ Echoing an earlier scene in which the bus had failed to stop, Gypsy spotlights the crisis of a Hamlet who is at one and same time bound for nowhere and caught in stasis. The only moving property is an ostrich, an émigré from a group of ostriches stolen by the shantytown Romanies in lieu of withheld payments. This isolated bird, like Adam/Hamlet, is a stranger in the settlement, yet, as surrogate, the ostrich also suggests symbolic money, a fragile economy, evaporating opportunities and the ceaseless struggle for resources. Most importantly, as his metaphorical equivalent moves outside the filmic frame, Adam/Hamlet remains confined within it. Key Hamletian questions about how to be and how to act, and key contemporary issues touching on disenfranchisement and dispossession, find no reply or remedy in an evocative but despairingly open-ended tableau.

Films like Hamlet, Ciganski Princ and Gypsy take us from high cultural Shakespeare to independent/unfamiliar Shakespeare, from established film directors to lesser known auteurs, from the artistic centre to the touchline of representation. In this process, Hamlet occupies a singular place as a resource through which the damaged constituencies and impoverished conditions of some parts of Russia, Central and Eastern Europe are lent creative expression. Marshalled for interrogative purposes, the play gives the lie to the notion that material growth and improvement are the defining features of the communist and post-communist worlds; rather, presenting anti-visions of the Soviet Union and after, Playing the Victim, Hamlet, Ciganski Princ and Gypsy puncture the narrative of progress, concentrating on separation and separateness, neglect and stigmatization - the peoples and societies that economic and political transformation leaves out. In this sense, at the same time as the distance travelled between Gamlet and its cinematic descendants signals far-reaching changes in terms of the organization of society and the role and definition of nation-states, it also confirms a shrinkage in the capacities of the subject, a diminution in the individual's worldview, and a decline in an idea of human dignity.

Playing the Victim, Hamlet, Ciganski Princ and Gypsy gravitate towards one other in the extent to which they dispassionately reflect upon the implications and

\footnotetext{
${ }^{8}$ The division is also suggested in dialogue: depending on the situation, Adam/Hamlet speaks either Slovak or the Roma language (the Spišská dialect).
} 
failures of political systems past and present, whether this shows itself in imagined projections of post-Soviet lives or in conceptually attuned stories of Roma existences that have slipped through the net of institutions such as the EU, which, as Aidan McGarry writes, "maintains Romaphobia through its commitment to neoliberalism", bolstering "economic marginalization" and "social inequities" (McGarry 2017: 9). Whatever generic choice is made for the play cinematically, its utility persists: travesty and tragedy mutually reinforce each other. The films explored in this paper engage with the spirit of Gamlet, but sculpt their own agendas for specific ends. In the hands of later filmmakers, space, once signifying hopes for agency or emancipation, becomes a physical phenomenon that cannot be overcome, unless in situations of wishfulfilment, make-believe and mediatised replay. Hamlet in its Russian, Central and Eastern European guises on film is fundamentally inflected by the political scene; it also intervenes in it in echoing and enervating conjurations of possible and ultimately impossible performances and economies. ${ }^{9}$

\section{References}

Adelman, J.(1992). Suffocating Mothers: Fantasies of Material Origin in Shakespeare's Plays, 'Hamlet' to 'The Tempest'. London and New York: Routledge.

Beumers, B. (2009). A History of Russian Cinema. Oxford and New York: Berg.

Beumers, B. and M. Lipovetsky (2009). Performing Violence: Literary and Theatrical Experiments of New Russian Drama. Bristol and Chicago: Intellect.

Black, J. L. (2004). Vladimir Putin and the New World Order: Looking East, Looking West? Lanham and New York: Rowman and Littlefield.

Burke, P. (1997). 'Hidden Games, Cunning Traps, Ambushes': The Russian Hamlet. Shakespeare Yearbook, 8, 163-80.

Burnett, M. T. (2019). 'Hamlet' and World Cinema. Cambridge: Cambridge University Press.

Collick, J. (1989). Shakespeare, Cinema and Society. Manchester and New York: Manchester University Press.

Fanon, F. (1986). Black Skin, White Masks, trans. by Charles Lam Markmann. London: Pluto Press.

Filčák, R. (2012). Living Beyond the Pale: Environmental Justice and the Roma Minority. Budapest and New York: Central European Press.

\footnotetext{
${ }^{9}$ My thanks to Dr. Nataša Šofranac for the generous invitation to speak at the BELLS 90 (2019) conference of the English Department, Faculty of Philology, University of Belgrade, and for stimulating conversation on all matters Shakespearean.
} 
Guy, W. (2001). The Czech Lands and Slovakia: Another False Dawn? In: W. Guy (ed.), Between Past and Future: The Roma of Central and Eastern Europe, Hatfield: University of Hertfordshire Press, 285-323.

Kaldova, J. (1991). The Gypsies of Czechoslovakia. In: D. Crowe and J. Kolsti (eds.), The Gypsies of Eastern Europe, Armonk and London: M. E. Sharpe, 93-115.

Leaming, B. (1980). Grigori Kozintsev. Boston: Twayne.

McGarry, A. (2017). Romaphobia: The Last Acceptable Form of Racism. London: Zed Books.

Makaryk, I. R. (2006). Wartime Hamlet. In: I. R. Makaryk and J. G. Price (eds.), Shakespeare in the Worlds of Communism and Socialism, Toronto, Buffalo and London: University of Toronto Press, 119-135.

Marušak, M. and L. Singer (2009). Social Unrest in Slovakia 2004: Romani Reaction to Neoliberal 'Reforms'. In: N. Sigona and N. Trehan (eds.), Romani Politics in Contemporary Europe: Poverty, Ethnic Mobilization, and the Neoliberal Order, Basingstoke: Palgrave, 186-208.

Matras, Y. (2015). The Romani Gypsies. Cambridge, Mass.: Harvard University Press. Norris, S. N. (2012). Blockbuster History in the New Russia: Movies, Memory, and Patriotism. Bloomington and Indianapolis: Indiana University Press.

Osborne, L. E. (1995). Filming Shakespeare in a Cultural Thaw: Soviet Appropriations of Shakespearean Treacheries in 1955-6. Textual Practice, 9, 325-47.

Pasqualino, C. (2008). The Gypsies, Poor but Happy. Third Text, 22, 37-345.

Powell, D. E. (2005). Putin, Demography, Health, and the Environment. In: D. R. Herspring (ed.), Putin's Russia: Past Imperfect, Future Uncertain. $2^{\text {nd }}$ edition. Lanham and New York: Rowman and Littlefield, 89-118.

Ringold, D., M. A. Orenstein and E. Wilkens (2005). Roma in an Expanding Europe: Breaking the Poverty Cycle. Washington, D.C.: The World Bank.

Rosefielde, S. and S. Hedlund (2009). Russia since 1980: Wrestling with Westernization. Cambridge: Cambridge University Press.

Rowe, E. (1976). Hamlet: A Window on Russia. New York: New York University Press. Semenenko, A. (2011). 'No Text Is an island': Translating Hamlet in Twenty-First Century Russia. In: B. J. Baer (ed.), Contexts, Subtexts and Pretexts: Literary Translation in Eastern Europe and Russia, Amsterdam and Philadelphia: John Benjamins, 249-263.

Severed Lives (2010). The Sunday Times Magazine, 25 July 2010, 42-43.

Shakespeare, W. (2016). Hamlet, edited by Ann Thompson and Neil Taylor. $2^{\text {nd }}$ edition. London and New York: Bloomsbury.

Sokolyansky, M. (2014). Russia. In: P. W. Marx (ed.), 'Hamlet' Handbuch: Stoffe, Aneignungen, Deutungen, Stuttgart and Weimar: Verlag J. B. Meltzler, 312-316. 
Sokolyansky, M. (2007). Grigori Kozintsev's Hamlet and King Lear. In: R. Jackson (ed.), The Cambridge Companion to Shakespeare on Film. $2^{\text {nd }}$ edition. Cambridge: Cambridge University Press, 203-215.

Thomas, A. (2014). Shakespeare, Dissent and the Cold War. Basingstoke and New York: Palgrave. 